\title{
The flavonoid from Polygonum perfoliatum L. inhibits herpes simplex virus 1 infection
}

\author{
Q.-G. ZHANG ${ }^{1}$, F. WEI', ${ }^{1,2}$, Q. LIU ${ }^{1}$, L.-J. CHEN 1 , Y.-Y. LIU' ${ }^{1}$, F. LUO' ${ }^{1}$, H.-R. XIONG ${ }^{1}$, Z.-Q. YANG ${ }^{*}$
}

\begin{abstract}
${ }^{1}$ State Key Laboratory of Virology, National Laboratory of Antiviral and Tumor of Traditional Chinese Medicine, Institute of Medical Virology, Research Center of Food and Drug Evaluation, School of Medicine, Wuhan University, Wuhan 430071, P. R China; ${ }^{2}$ School of Basic Medicine, Hubei University of Chinese Medicine, Wuhan 430065, P. R. China
\end{abstract}

Received February 24, 2014; accepted November 13, 2014

\begin{abstract}
Summary. - Herpes simplex virus 1 (HSV-1) is one of the most prevalent human pathogens in both industrialized and developing countries. This study was performed to analyze the antiviral activity of purified flavonoid from Polygonum perfoliatum L. against HSV-1 infection in vitro and in vivo. Flavonoid showed no inhibitory effect, when treated before virus infection, but it strongly inhibited viral replication and cell-to-cell spread which was vital for the virus's propagation. The therapeutic effect of the flavonoid in treating HSV-1 induced encephalitis was also investigated in mice. A dose-dependent increase of survival rate and mean survival time (MST) were observed in the flavonoid-treated mice. These results suggested that the flavonoid may be a viable therapeutic option for recurrent HSV-1 infection.
\end{abstract}

Keywords: herpes simplex virus 1; flavonoid; Polygonum perfoliatum L.; antiviral, Hep-2 cell; mouse

\section{Introduction}

Herpes simplex virus 1 (HSV-1) is enveloped, double stranded DNA virus that belongs to the Herpesviridae family (Emmert, 2000). As one of the most ubiquitous human viral pathogens, HSV-1 infections have been designated as the predominant cause of recurrent infection for orofacial and ocular mucocutaneous lesions, and is estimated to infect approximately more than one-third of the world's population, among which 10 to $20 \%$ experiences recurring outbreaks (Hayashi et al., 2012). HSV-1 is transmitted primarily through the oral route, causing diseases like keratoconjunctivitis, neonatal HSV infection or encephalitis, a devastating disease in the absence of sufficient antiviral treatment

*Corresponding author. E-mail: zqyang@whu.edu.cn; phone: +862768759136 .

Abbreviations: $\mathrm{ACV}=$ acyclovir $\mathrm{EC}_{50}=50 \%$ effective concentration; HSV-1 = herpes simplex virus 1; IFA = immunofluorescence assay; $\mathrm{MST}=$ mean survival time; p.i. = post infection; $\mathrm{SI}=$ selectivity index; $\mathrm{TC}_{50}=50 \%$ toxic concentration
(Superti et al., 2008). After replication at sites of initial inoculation, HSV-1 establishes latency to avoid clearance by the immune system by entering trigeminal ganglion and periodically reactivates in response to various types of physiologic stress, making successful vaccine development a challenge (Holmgren et al., 2003). Severe HSV-1 infections are often observed in vulnerable patient populations such as newborns or immunocompromised individuals (Lyu et al., 2005; Marris, 2005). Currently, the only herpes medication relies on the nucleoside and nucleotide analogues such as acyclovir (ACV) (Luck et al., 2006). However, viral resistant variants emerged due to the prolonged or extensive clinical usage of ACV and ACV-like drugs in immunocompetent patients (Luck et al., 2006). Therefore, there is an urgent need for novel anti-HSV drugs, especially those with different antiviral intervention strategies.

P. perfoliatum L. (commonly known as mile-a-minute weed) is a herbaceous, medicinal plant widely distributed around the world. In traditional Chinese medicine, $P$. perfoliatum L. known as Gangbangui, is valued for its diuretic, anti-inflammatory, and other effects. As one of the oldest Chi- 
nese herbal medicines, many bioactive substances have been successfully isolated from $P$. perfoliatum L., such as quercetin, and protocatechuic acid, etc. Among the bioactive properties, flavonoid offers a number of promising features (Li et al., 2000; Nijveldt et al., 2001). Flavonoids are one of the plant-derived secondary polyphenolic metabolites which are ubiquitous in nature and abundantly present throughout a variety of herbal plants (Goncalves et al., 2001). The flavonoids have recently aroused considerable interest because of their potential beneficial effects on human health. Many pharmacological properties of flavonoids, especially antiviral actions have been reported in the scientific literature (Hayashi et al., 2012; Nijveldt et al., 2001). Studies have demonstrated that the flavonoids extracted from herbs in addition to different properties like anti- allergic, inflammatory, microbial and cancer activity, they also exert antiviral activities against a wide spectrum of vicious human pathogens, including human immunodeficiency virus type 1 , herpes simplex virus, vesicular stomatitis virus and human cytomegalovirus (Cefarelli et al., 2006; Kralj et al., 2013; Li et al., 2000; Middleton et al., 2000). These findings are crucial for understanding the pharmacological properties of flavonoids which, despite extensive studies of different flavonoid antiviral properties derived from $P$. perfoliatum L., are still incompletely understood.

The aim of this study was to investigate flavonoid derived from $P$. perfoliatum L. for its anti-herpetic activity in vitro and in vivo. We concluded that the flavonoid may serve as a promising agent in combating HSV-1infection in consideration of its ability to disrupt viral life cycle.

\section{Materials and Methods}

The flavonoid. Polygonum perfoliatum L. was purchased from local herbal market in August 2012. The identification and authenticity were confirmed by professional medicinal plant experts. Dried and powdered leaves of $P$. perfoliatum L. were extracted by Soxhlet apparatus (Shanghai Yuane Industrial Co., Ltd.) with n-hexane and methanol. The methanol extract obtained was partitioned with ethyl acetate and concentrated using a rotary evaporator to provide the flavonoid fraction. The quantity of flavonoid was determined by HPLC analysis. ACV was purchased from Tianjing Pharmaceutical Co, LTD (China).

Virus and cells. Human laryngeal carcinoma (HEp-2, ATCC) cells were propagated in DMEM supplemented with 10\% FBS (Gibco), $100 \mathrm{IU} / \mathrm{ml}$ penicillin, $100 \mu \mathrm{g} / \mathrm{ml}$ streptomycin, and $0.1 \%$ L-glutamine. HSV-1 (Sm44 strain) was propagated in HEp-2 cells. Virus titrations were performed by the plaque assay and expressed as $\operatorname{TCID}_{50}$.

Cell viability assay. Serial two-fold dilutions of the compound were added to the cells and incubated for $72 \mathrm{hr}$ at $37^{\circ} \mathrm{C}$ in a humidified atmosphere containing $5 \% \mathrm{CO}_{2}$. Following incubation, cells were incubated in MTT solution for $4 \mathrm{hr}$, and the absorbance was measured with a conventional microplate reader $\left(\mathrm{A}_{490}\right) . \mathrm{TC}_{50}$ of the chemical was calculated.

Experiments on virucidal activity of the flavonoid. Serial two-fold dilutions of the flavonoid were incubated with HEp-2 cell monolayers for $2 \mathrm{hr}$ at $37^{\circ} \mathrm{C}$. After incubation, the cells were washed three times with PBS to remove unreacted flavonoid and infected with $100 \mathrm{TCID}_{50}$ HSV-1 to allow plaque formation. To determine the direct effect of the flavonoid on HSV-1, HSV-1 stock containing 100 $\mathrm{TCID}_{50}$ of virus were either treated with an equal volume of different concentrations of the flavonoid or with drug-free vehicle at $4^{\circ} \mathrm{C}$ for $1 \mathrm{hr}$. The residual infectivity of virus was further determined by immediate inoculating onto HEp-2 cells to allow plaque forming in agarose medium. The $\mathrm{EC}_{50}$ was determined and expressed as the following formula: $\mathrm{SI}=\mathrm{TC}_{50} / \mathrm{EC}_{50}$.

Experiments on the activity of the flavonoid to inhibit virus replication. HEp-2 cell were challenged with 100 TCID $_{50}$ HSV-1 for $1 \mathrm{hr}$. After thoroughly washing unbound virus, the cells were replaced with agarose medium containing different concentrations of the flavonoid. The antiviral activity of the flavonoid was determined by plaque assay.

Immunofluorescence assay (IFA). HEp-2 cells were infected with 100 TCID $_{50}$ HSV-1 and incubated with different concentrations of the antiviral drugs. Cells were then fixed with ice-cold methanol followed by incubation with primary antibody against HSV-1 gC (Santa Cruz, 1:200). Following rinsing with PBS, specific FITC-

(a)

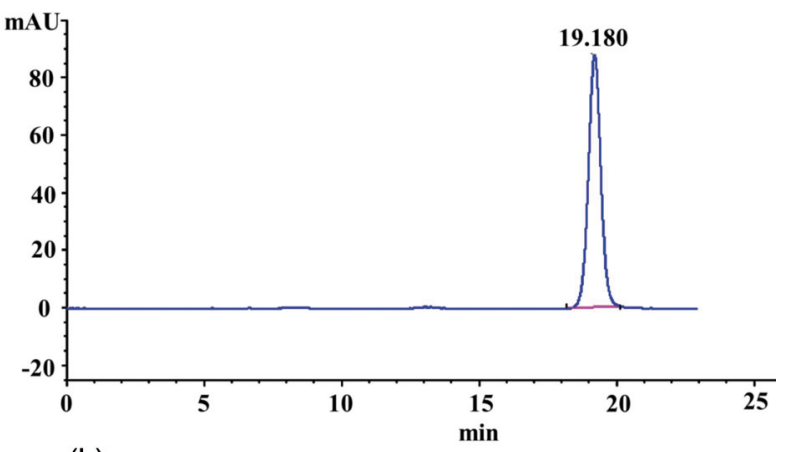

(b)

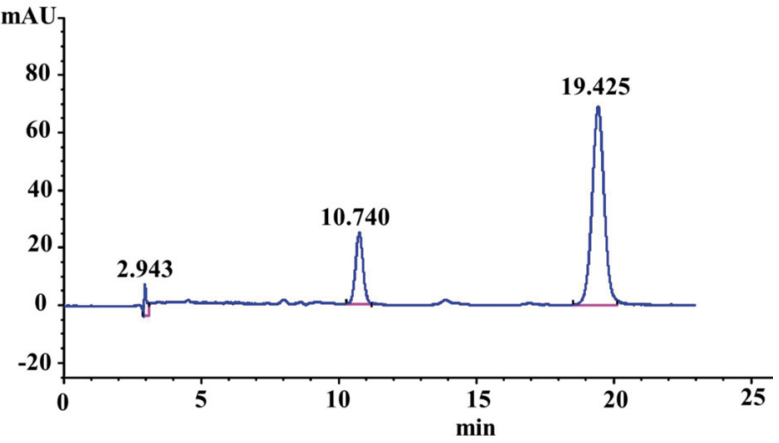

Fig. 1

HPLC analysis of the flavonoid. Rutin as standard (a), the flavonoid (b) 
Table 1. Cytotoxicity of the flavonoid to Hep-2 cells

\begin{tabular}{lccc}
\hline Compound & Cytotoxicity TC $_{50}(\mu \mathrm{g} / \mathrm{ml})$ & Virucidal activity EC $_{50}(\mu \mathrm{g} / \mathrm{ml})[\mathrm{SI}]$ & Antiviral activity $\mathrm{EC}_{50}(\mu \mathrm{g} / \mathrm{ml})[\mathrm{SI}]$ \\
\hline Flavonoid & 244.0 & $55.1[4.4]$ & $29.9[8.2]$ \\
ACV & 510.95 & ND & $57.9[8.8]$ \\
\hline
\end{tabular}

aThe activity inhibiting virus replication. $\mathrm{TC}_{50}=50 \%$ toxic concentration; $\mathrm{EC}_{50}=50 \%$ effective concentration; $\mathrm{SI}=\mathrm{TC}_{50} / \mathrm{EC}_{50} ; \mathrm{ND}=\mathrm{not}_{\mathrm{determined}}$

conjugated IgG (Santa Cruz, 1:1000) secondary antibody was added to the cells. Cells were counterstained with Evans blue and analyzed by the observation under the fluorescence microscope (Nikon TE2000).

Experiments on mice. BALB/c mice were purchased from the Animal Research Center of Wuhan University (Certificate No. SCXK 2008-0004, Hubei). Mice were handled in accordance with guidelines approved by the Institutional Animal Care and Use Committee (China). BALB/c mice were infected intracerebrally with $20 \mu \mathrm{l}$ of viral suspension containing 10 median lethal dose $\left(10 \mathrm{LD}_{50}\right)$ of HSV-1. The mice infected with virus were randomly divided into 5 groups; flavonoid at a dose of $30,15,7.5 \mathrm{mg} / \mathrm{kg} /$ day, and ACV at a dose of $50 \mathrm{mg} / \mathrm{kg} /$ day were orally administered two times daily to the mice (at $12 \mathrm{hr}$ intervals) for 7 consecutive days after virus inoculation. Body weight of mice was recorded dailyfor 20 days.

Statistical analysis. The data were analyzed with SPSS 17.0 software package (SPSS Inc., USA). Data are presented as mean \pm S.D. of three independent experiments and examined by the twosample test or one-way analysis of variance. Differences among drug treatments and controls were analyzed in repeated measures with Analysis of Variance (ANOVA). $P \leq 0.05$ was considered significant.

\section{Results}

\section{Cytotoxicity of the flavonoid}

In order to rule out any direct cytotoxic effect of the flavonoid, cells were treated with different concentrations of drug. As shown in Table 1, the $\mathrm{TC}_{50}$ of the flavonoid on HEp-2 cells was $244 \mu \mathrm{g} / \mathrm{ml}$. None of the concentrations used in the subsequent experiments affected the cell density of confluent cultures or caused morphological signs of cytotoxicity.

\section{Pretreatment and virucidal activity of the flavonoid}

HEp-2 cells were preincubated with the flavonoid at various concentrations prior to HSV-1 inoculation. Treatment of cultures for $2 \mathrm{hr}$ with $62.5 \mu \mathrm{g} / \mathrm{ml}$ flavonoid before infection did not show any significant decrease in the plaques numbers (Fig. 2). There was no significant difference between flavonoid-treated groups and the untreated virus control.
These results indicated that the flavonoid could not block viral adsorption to HEp-2 cells. Furthermore, several published researches by other investigators also indicated that the mechanism of antiviral activities of flavonoid derived from other sources possess ability of direct inactivation of infectious viral particles. In order to assess whether the flavonoid could have a similar mechanism, viral inoculum was incubated with serial dilutions of the flavonoid for $1 \mathrm{hr}$ prior to inoculation on HEp-2 cells. As shown in Table 1, the $\mathrm{EC}_{50}$ of the flavonoid on HEp-2 cells was $55.1 \mu \mathrm{g} / \mathrm{ml}$ in virucidal assay, with the SI calculated as 4.4. These results indicated that the flavonoid could directly inactivate HSV-1 virion (Fig. 2a).

\section{Inhibition of virus replication by the flavonoid}

To determine whether the flavonoid could inhibit viral replication and dissemination, HEp-2 cells were inoculated with HSV-1 then overlaid with agarose containing various concentrations of antiviral drugs. As shown in Fig. 2b, the effective dose of the flavonoid on HSV-1 started from $15.6 \mu \mathrm{g} / \mathrm{ml}$. The $\mathrm{EC}_{50}$ of the isolated flavonoid was $29.9 \mu \mathrm{g} / \mathrm{ml}$ in the posttreatment assay. Flavonoid at a concentration of $62.5 \mu \mathrm{g} / \mathrm{ml}$ was effective at reducing the number of plaques in infected cultures by more than $80 \%$ as compared the viral control (Fig. 2b). The antiviral effect enhanced correspondingly with the increase of the dosage. The inhibitory effects of the flavonoid against HSV-1 infection were equivalent to the conventional antiviral ACV regarding to the $\mathrm{SI}(P>0.05)$. To further determine the in vitro therapeutic effect of the flavonoid against HSV-1 infection, viral antigens of HSV-1 infected cells were determined by IFA using anti-HSV-1 antibodies. In the presence of $62.5 \mu \mathrm{g} / \mathrm{ml}$ and $7.8 \mu \mathrm{g} / \mathrm{ml}$ of flavonoid, HSV-1 infection was dramatically reduced in a concentration-dependent manner (Fig. 3).

\section{Therapeutic effect of the flavonoid on virus-infected mice}

We used the HSV-1 (sm44 strain) to induce encephalitis in a BALB/c mouse model. Typical symptoms of mice intracerebrally infected with HSV-1 showed habitus of progressively diminished vitality, scrubby coat, hunchback, paralysis of limbs, and a distinct loss of weight. However, the clinical signs were less pronounced in the flavonoid-treated mice compared to viral control mice. Eight days after virus infec- 
(a)

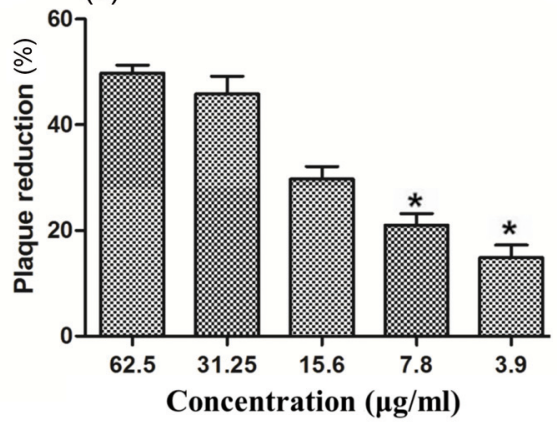

(b)

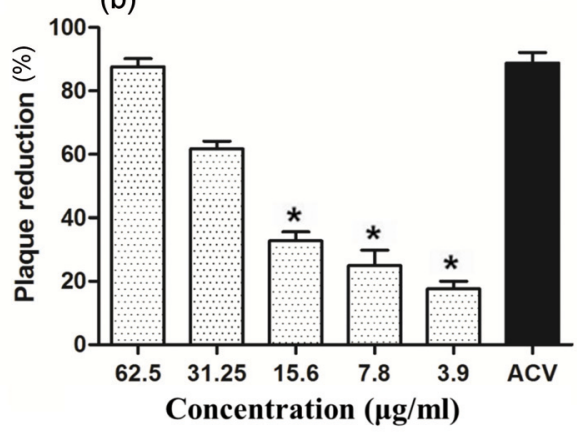

Fig. 2

Virucidal (a) and virus replication inhibiting (b) activities of the flavonoid Inhibition of virus replication followed in Hep-2 cells.

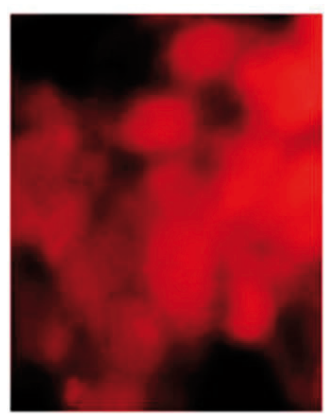

NC

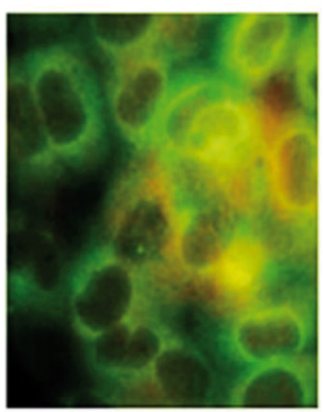

VC

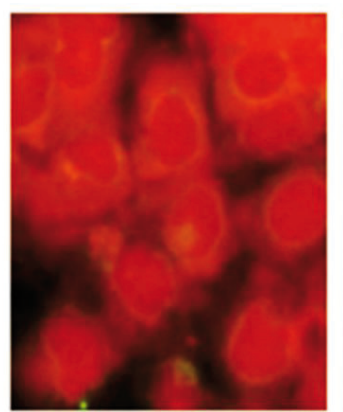

$62.5(\mu \mathrm{g} / \mathrm{ml})$

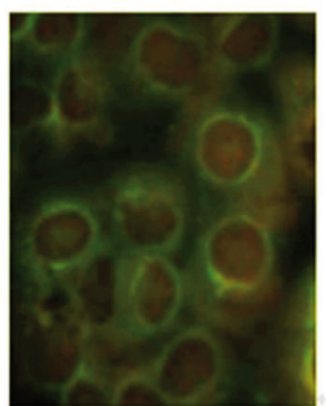

$7.8(\mu \mathrm{g} / \mathrm{ml})$

Fig. 3

Detection of viral antigen in virus-infected Hep- 2 cells by IFA

Negative control (NC), virus control (VC) and effects of $62.5 \mu \mathrm{g} / \mathrm{ml}$ and $7.8 \mu \mathrm{g} / \mathrm{ml}$ of flavonoid.

(a)

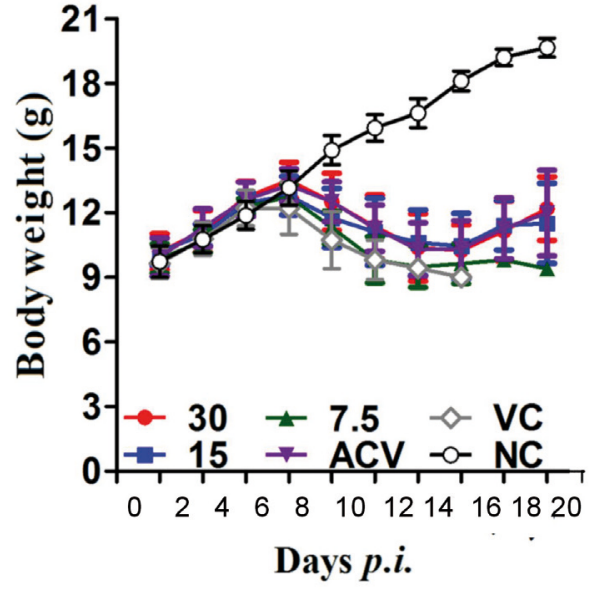

(b)

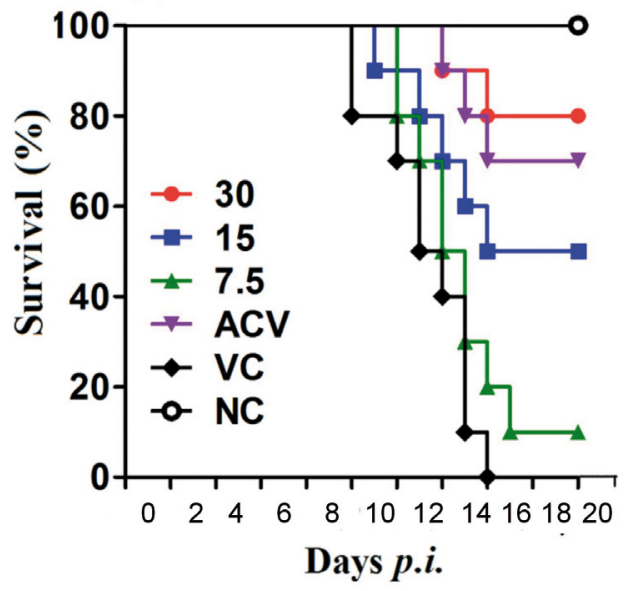

Fig. 4

Effects of the flavonoid on virus-infected mice

Changes in the body weight (a) and mortality (b) on days 2-20 post infection under the influence of 30,15 and $7.5 \mathrm{mg} / \mathrm{kg} / \mathrm{day}$ flavonoid. 
Table 2. Therapeutic effect of the flavonoid on HSV-1-induced encephalitis in mice

\begin{tabular}{|c|c|c|c|c|}
\hline Treatment & Dose & Dead/Total & Mortality (\%) & MST(days) \\
\hline \multirow{3}{*}{ Flavonoid } & $30 \mathrm{mg} / \mathrm{kg} /$ day & $2 / 10$ & 20.00 & $19.0 \pm 2.1^{*}$ \\
\hline & $15 \mathrm{mg} / \mathrm{kg} /$ day & $5 / 10$ & 50.00 & $16.9 \pm 3.3^{*}$ \\
\hline & $7.5 \mathrm{mg} / \mathrm{kg} /$ day & $9 / 10$ & 90.00 & $14.8 \pm 2.3$ \\
\hline $\mathrm{ACV}$ & $50 \mathrm{mg} / \mathrm{kg} /$ day & $3 / 10$ & 30.00 & $18.5 \pm 2.3^{*}$ \\
\hline Positive control & - & $10 / 10$ & 100.00 & $13.3 \pm 2.0$ \\
\hline Negative control & - & $0 / 10$ & 0 & - \\
\hline
\end{tabular}

*Significant difference from the positive control.

tion, all infected mice exhibited a reduction of body weight. However, all treated animals began to recover from disease in a dose-dependent manner and gained weight again at 14 days post infection $(\mathrm{Fa})$. The virus-infected, placebo-treated mice showed no apparent increase of body weight at 14 days post infection. As shown in Table 2, the survival rate of the $30 \mathrm{mg} / \mathrm{kg} / \mathrm{day}(2 / 10,80.0 \%)$ and $15 \mathrm{mg} / \mathrm{kg} /$ day $(5 / 10$, $50.00 \%)$ increased dramatically compared to virus control group. The survival rate increased and MST prolonged in the treated groups of the infected mice (Fig. 4b). The MST of the 30,15 and $7.5 \mathrm{mg} / \mathrm{kg} /$ day flavonoid-treated group were $19.0 \pm 2.1,16.9 \pm 3.3,14.8 \pm 2.3$ days (Table 2 ). Considerably significant differences were calculated between the flavonoidtreated mice (30 and $15 \mathrm{mg} / \mathrm{kg} /$ day) and virus control mice at days 8 until 20 days post inoculation. The $30 \mathrm{mg} / \mathrm{kg} /$ day flavonoid-treated mice showed favorable survival rate and longer MST, which were equivalent to ACV treatment $(3 / 10$, $18.5 \pm 2.3)$ group $(P \leq 0.05)$. These data further revealed that the flavonoid may also be therapeutically effective in treating HSV-1infection in mice.

\section{Discussion}

HSV-1 encephalitis is the one of the most common causes of fatal encephalitis worldwide. Search for novel effective therapeutic agents remains compulsory. Previous data indicated that smashed fresh or dried leaves of P. perfoliatum L. have been used extensively in Chinese folk remedy to treat recurrent herpes infection. As one of the most abundant and active ingredient from $P$. perfoliatum $\mathrm{L}$., we tested the potential therapeutic effect of flavonoid in treating HSV-1 infection in vitro and in vivo. Previously, experimental and clinical data have demonstrated the $P$. perfoliatum L. and its methanol extract can be used to treat various inflammatory diseases such as rheumatoid arthritis, indicative of anti-inflammatory effect of P. perfoliatum L. (Cheng et al., 2012; Fan et al., 2011). Several other studies also indicated the antioxidant and antiviral effects of flavonoid from medicinal herbs (Nijveldt et al., 2001). Although there are many reports on the antiviral activity of flavonoids, only few studies have investigated their mechanism of action. In this study, different stages of viral replication cycle were investigated, with the most effective inhibition observed when posttreatment of infected HEp-2 cells with the flavonoid was used, indicating a protective effect of flavonoid in terms of the release of mature viral particles from previously infected cells. Previous studies demonstrated that flavonoid derived from green tea potently inhibited cell-culture-derived HCV ( $\mathrm{HCVcc}$ ) entry into hepatoma cell lines rather than affecting HCV RNA replication or release of progeny virions (Calland et al., 2002). However, we did not observed any apparent inhibitory effect of the flavonoid on viral adsorption to HEp-2 cells. It was also reported that flavonoid from Ocotea notata leaves have been shown to exhibit extracellular virus-inactivating activity, as observed in the present study (Kralj et al., 2013). HSV enters cells by fusion with plasma membranes through a process carried out by the sequential activity of envelope glycoproteins, including $\mathrm{gB}$ and $\mathrm{gD}$, etc. Both $\mathrm{gB}$ and $\mathrm{gD}$ are essential for HSV entry into cells (Johnson et al., 2011). A number of studies provide evidence that flavonoids with anti-HSV activity operate by disruption of $\mathrm{gB}$ or direct effect on the virion from either HSV-1 or HSV-2 (Isaacs et al., 2008). This can explain why the flavonoid demonstrates extracellular virus-inactivating activity in our experiment. Proposed antiviral mechanisms of action of flavonoids also include inhibition of viral proteins related to replication and binding of viral nucleic acid (Coulerie et al., 2013). In our study, the inhibitory effects of the flavonoid on HSV-1 were tested by IFA and plaque assay. The results of IFA were also consistent with the data from the plaque assay, demonstrating that the flavonoid could both inactivate HSV-1 directly and interfere with virus replication.

We then employed an HSV-infected BALB/c mouse model which can be used to evaluate the in vivo therapeutic effect. In our study, the flavonoid-treated mice showed better survival rate and prolonged mean survival time compared to the virus control group. The therapeutic effect of $30 \mathrm{mg} / \mathrm{kg} /$ day flavonoid-treated group was equivalent to ACV at a dose of $50 \mathrm{mg} / \mathrm{kg} /$ day. Based on our results we suggest that the flavonoid could be used as complement in treating HSV-1 infections due to different viral inhibition strategies and low toxicity. 
Acknowledgements. The authors thank Prof. Keli Chen, College of Pharmacy, Hubei University of Traditional medicine for the collection and identification of the plant material used in this experiment, Vytas Raulinaitis and Jia-xin Ling from the University of Helsinki, Finland for their language-related comments on the manuscript.

\section{References}

Calland N, Albecka A, Belouzard S, Wychowski C, Duverlie G, Descamps V, Hober D, Dubuisson J, Rouille Y, Seron, $\mathrm{K}$ (2002): (-)-Epigallocatechin-3-gallate is a new inhibitor of hepatitis C virus entry. Hepatology 55, 720-729. http:// dx.doi.org/10.1002/hep. 24803

Cefarelli G, D'Abrosca B, Fiorentino A, Izzo A, Mastellone C, Pacifico S, Piscopo V (2006): Free-radical-scavenging and antioxidant activities of secondary metabolites from reddened cv. Annurca apple fruits. J. Agric. Food Chem. 54, 803-809. http://dx.doi.org/10.1021/jf052632g

Cheng HB, Liu XQ, Chen KL (2012): Chemical constituents of ethyl acetate extract from Polygonum perfoliatum. Zhong Yao Cai 35, 1088-1090.

Coulerie P, Nour M, Maciuk A, Eydoux C, Guillemot J C, Lebouvier N, Hnawia E, Leblanc K, Lewin G, Canard B, Figadere B (2013): Structure-activity relationship study of biflavonoids on the Dengue virus polymerase DENV-NS5 RdRp. Planta Med. 79, 1313-1318. http://dx.doi.org/10.1055/s0033-1350672

Emmert DH (2000): Treatment of common cutaneous herpes simplex virus infections. Am. Fam. Physician 61, 1697-1704.

Fan D, Zhou X, Zhao C, Chen H, Zhao Y, Gong X (2011): Antiinflammatory, antiviral and quantitative study of quercetin-3-O-beta-D-glucuronide in Polygonum perfoliatum L. Fitoterapia 82, 805-810. http://dx.doi.org/10.1016/j. fitote.2011.04.007

Goncalves JL, Leitao SG, Monache FD, Miranda MM, Santos MG, Romanos MT, Wigg MD (2001): In vitro antiviral effect of flavonoid-rich extracts of Vitex polygama (Verbenaceae) against acyclovir-resistant herpes simplex virus type 1 . Phytomedicine 8, 477-480. http://dx.doi.org/10.1078/ $\underline{\text { S0944-7113(04)70069-0 }}$

Hayashi K, Iinuma M, Sasaki K, Hayashi T (2012): In vitro and in vivo evaluation of a novel antiherpetic flavonoid, 4'phenylflavone, and its synergistic actions with acyclovir.
Arch. Virol. 157, 1489-1498. http://dx.doi.org/10.1007/ s00705-012-1335-6

Holmgren J, Czerkinsky C, Eriksson K, Mharandi A (2003): Mucosal immunisation and adjuvants: a brief overview of recent advances and challenges. Vaccine 21 (Suppl. 2), S89-95. http://dx.doi.org/10.1016/S0264-410X(03)00206-8

Isaacs CE, Wen GY, Xu W, Jia J H, Rohan L, Corbo C, Di Maggio V, Jenkins EC Jr, Hillier S (2008): Epigallocatechin gallate inactivates clinical isolates of herpes simplex virus. Antimicrob. Agents Chemother. 52, 962-970. http://dx.doi. org/10.1128/AAC.00825-07

Johnson DC, Wisner TW, Wright CC (2011): Herpes simplex virus glycoproteins $\mathrm{gB}$ and $\mathrm{gD}$ function in a redundant fashion to promote secondary envelopment. J. Virol. 85, 4910-4926. http://dx.doi.org/10.1128/JVI.00011-11

Kralj A, Nguyen MT, Tschammer N, Ocampo N, Gesiotto Q, Heinrich MR, Phanstiel Ot (2013): Development of flavonoidbased inverse agonists of the key signaling receptor US28 of human cytomegalovirus. J. Med. Chem. 56, 5019-5032. http://dx.doi.org/10.1021/jm4003457

Li BQ, Fu T, Dongyan Y, Mikovits JA, Ruscetti FW, Wang JM (2000): Flavonoid baicalin inhibits HIV-1 infection at the level of viral entry. Biochem. Biophys. Res. Commun. 276, 534-538. http://dx.doi.org/10.1006/bbrc.2000.3485

Luck S, Sharland M, Griffiths P, Jenkins SM (2006): Advances in the antiviral therapy of herpes virus infection in children. Expert Rev. Anti. Infect. Ther. 4, 1005-1020. http://dx.doi. org/10.1586/14787210.4.6.1005

Lyu SY, Rhim JY, Park WB (2005): Antiherpetic activities of flavonoids against herpes simplex virus type 1 (HSV-1) and type 2 (HSV-2) in vitro. Arch. Pharm. Res. 28, 1293-1301. http://dx.doi.org/10.1007/BF02978215

Marris E (2005): Invasive species: shoot to kill. Nature 438, 272-273. http://dx.doi.org/10.1038/438272a

Middleton E, Jr., Kandaswami C, Theoharides TC (2000): The effects of plant flavonoids on mammalian cells: implications for inflammation, heart disease, and cancer. Pharmacol. Rev. 52, 673-751.

Nijveldt RJ, van Nood E, van Hoorn, DE, Boelens PG, van Norren K, van Superti F, Ammendolia MG, Marchetti M (2008): New advances in anti-HSV chemotherapy. Curr. Med. Chem. 15, 900-911. http://dx.doi. org/10.2174/092986708783955419 